\title{
The Child-murdering Mother: Dionysian or Apollonian? A Study of Nietzsche's View on Euripidean Tragedy
}

\author{
Bahee Hadaegh \\ Shiraz University, Iran \\ Parisa Shams \\ Shiraz University, Iran
}

\begin{abstract}
This paper aims at delving into the play Medea in the light of Nietzsche's views on tragedy expressed in his book The Birth of Tragedy. First, Nietzsche's conception of Apollonian-Dionysiac duality will be explained, followed by a review of how he regards Eurpides, and then, the pro and con views on Euripidean tragedy will be examined. Finally the play Medea will be analyzed to designate how and in what sense it departures from, or approaches either of the Apollonian or Dionysian spirits. In what ways, the character of a mother who commits infanticide can be interpreted as rational or insane? To what extent is Medea in line with Nietzsche's assertion that Euripides is the advocate of rationality, departing from the Dionysian spirit of tragedy?
\end{abstract}

Index Terms-Eurpides, Nietzsche, Medea, Apollonian, Dionysiac, Socratism, Greek tragedy

\section{NIETZSCHE'S CONCEPT OF APOLLONIAN-DiONYSIAC DUALITY}

The Apollonian-Dionysiac duality underlies the constant evolution of art, just as the duality of the sexes is responsible for the reproduction of the species. Apollo and Dionysus, the "art-sponsoring" deities, must be understood in order to distinguish between "the plastic, Apollonian arts and the non-visual art of music inspired by Dionysos."'These two creative tendencies grew in opposition side by side, until the pair yielded to marriage and gave birth to Attic tragedy exhibiting the traits of both parents. (Nietzsche, 1956, p. 19)

The Apollonian tendency in art corresponds to the realm of dream, and the Dionysiac, to the realm of intoxication. Apollo is the god of measured restraint, illusion, and the divine image of the principle of individuation. It expresses the "deep and happy sense of the necessity of dream." The Dionysiac power forges the bond between man and man, and between man and nature. By the magic of the Dionysiac rite, the individual, expressing himself through song and dance, reconciles with his fellow and himself and becomes a member of a higher community. He becomes a work of art, manifesting the creative power of the universe. (Nietzsche, 1956, p. 19-24)

Nietzsche (1956) believes that Greek tragedy is a Dionysiac chorus which frequently discharges itself in Apollonian images. The foundation of tragedy irradiates the vision of the drama, which is, on the one hand, completely a dream image and epic in nature, and on the other hand, the shattering of individuality as the embodiment of a Dionysiac condition. "Thus, tragedy is the Apollonian embodiment of Dionysiac knowledge and powers, and therefore, immensely distinct from epic" (p. 56-57).

In the apollonian part of Greek tragedy, which is the dialog, whatever that comes to the surface seems "simple, transparent, beautiful." The dialog, hence, reflects the Greek mind, whose nature reveals itself in dance (Nietzsche, 1956, p. 59).

\section{NIETZSCHE'S VIEW OF EURPIDES}

Greek tragedy, in its oldest form, dealt only with the sufferings of Dionysus and Dionysus did not cease to be the tragic hero up to the time of Eurpides. (Nietzsche, 1956, p. 65-66) Eurpides is, then, responsible for the death of Greek tragedy (Nietzsche, 1956, p. 69).

Euripides appealed to the writers of the new comedy. What they found so exciting in him was his success in bringing the spectator on the stage. This way, the common man pushed his way out of the auditorium and found his way on the stage. He could now see his counterpart on the stage, taking delight in finding him speaking so eloquently. Eurpides taught people how to speak, he presented ordinary living and a portrayal of life as it really is, and it was to his credit that people were inculcated with wisdom and judgment. Thus arose the New Comedy, as the chorus started to sing the Euripidean musical key. People would have wished to learn more from Euripides and praise him dearly if they were unaware that tragedy, and the tragic poets were then dead. With the death of tragedy, the belief in immortality died, and it meant the death of faith in the ideal past and also the ideal future (Nietzsche, 1956, p. 70-72) 
Cowan (2007) comments that for Nietzsche, Socratism is built upon the destruction of myth which is tragedy's means to unify a culture. By death of tragedy, its irrational sources broke into parts, and the Greeks gave up their faith in immortality, the ideal past and the ideal future, because the myths that held culture together disappeared by the disappearance of tragedy. It is indicative of the inextricable role of myth, custom and tragedy in Greek's national character. (p. 548) Therefore, the imprint of what Eurpides did to tragedy is as immense as the dimensions of a nation, a culture and a history.

For Nietzsche, what constitutes the bond between Eurpides and Socrates is that both men feel the obligation to rely on their conscious reason to reach the effect they seek, didactic teaching is the purpose of both, and as ideal spectator, neither of them "can accept the illusion that had completed the Dionysian-Apollonian unity in Aeschylean drama." They found Dionysus incomprehensible and thus, Eurpides quits Dionysus and himself is abandoned by Apollo consequently. He deals with the same myths as other dramatist did; but he substitutes naturalistic effects as he finds inaccessible the underworld which gave the myths power (Strong, 1975, p. 173). Strong concludes from Nietzsche's words that "Euripides is too critical to permit himself to accept older drama. For Euripides, to do the right in this historical situation requires knowledge." (p. 172)

\section{CONFLICTING VIEWS ON EURIPIDEAN TRAGEDY}

When Nietzsche (1956) asserted in his essay that Eurpides, by devotion to Socrates, threw out of balance the two primary forces in human spirit and destroyed Greek tragedy, he was severely attacked by Wilamowitz who offered a modern study of Greek tragedy and a defense of Eurpides. (Mitchell-Boyask, 2008, p. xvii) Wilamowitz attacked the tone of the book, its style, logic and lack of scholarship. He accused Nietzsche of being ignorant and dishonest, calling his arguments implausible and relying on unstated evidence. (Silk and Stern, 1981, p. 96)

Nussbaum (1988), being at odds with Nietzsche, believes that while many of the observations Nietzsche has made about ancient literature are deeply illuminating, his treatment of Euripides in The Birth of Tragedy, remarkably lacks insight. He holds the view that Nietzsche's is an astonishing account of Euripidean tragedy, because it is hard to believe that Nietzsche could interpret Hyppolitus and Medea "as defenses of the omnipotence of reason." One can hardly point out a Euripidean play to which the Nietzschean interpretation is at first sight applicable. (p. 36-37)

Kaufmann (1968) asserts that Nietzsche is mistaken in claiming that tragedy died at the hands of Euripides. (p. 243) He believes that Nietzsche had fallen in with an old prejudice against Euripides and was intensely unfair to him. (p. 246)

Silk and Stern (1981) maintain that "Nietzsche is not renowned for his fairness" and his critique of Euripides is extremely unfair, but has received scholarly confirmation as well. (p. 258) His condemnation of Euripides as the destroyer of traditional myth is confirmed by D.H. Lucas, when he asserts:

In Euripides' plays... there appears a loss of confidence in the innate significance of the old stories and the readiness to give them an unnatural twist in order that they may fulfill momentarily a new purpose. Jason and Medea, selfish male and passionate woman, belong only intermittently to the heroic world. (qtd. in Silk and Stern, 1981, p. 258)

"In what sense, if any, can Euripides be called a rationalist?" This question was once posed by E.R Dodds in opposition to the thesis of the Birth of Tragedy (Silk and Stern, 1981, p. 260). Dodds declares that Greek culture died of systematic rationalism, the attack of which, in the fifth century, is proved by the case of Euripides who shows all the characteristic symptoms such as combining skepticism and mysticism, valuing emotion over reason, despair of the state and rational theology, and "craving for a religion of the orgiastic type". (Kaufmann, 1968, p. 256-257)

Dodds pronounced Euripides an irrationalist, defining rationalism in terms of three beliefs that could not be attributed to Euripides: "reason as the instrument of truth-as the essential character of reality-as the means to personal redemption." To support his case, he takes as an example the inability of Medea's reason to prevent her from childmurder. However Dodds fails to draw the conclusion that Euripides may not adhere to this formulae for rationalism, but "he would dearly like to". So, up to a point, Nietzsche is right in associating Euripides with rationalism and Socrates. (Silk and Stern, 1981, p. 260)

As to condemn Eurpides, Smith (1998) states that Eurpides intended to obliterate "the Dionysian acoustical root of the Apollonian visual dream." By doing so, he gave tragedy an empty lifeless form. Tragedy was then " a mere 'game of chess', mere 'cool thoughts' into which he then imported 'fiery affects', say, in Medea's gruesome violence." He goes on to note that Eurpides' Medea differs from "Aeschylus's Dionysian chorus of furies", in that she is a barbarian from the exotic east, not coming from "the underground chaos preceding Greek Olympian order." (p. 300)

Some believe that Eurpides does not intend to destroy tradition and myth; rather, he has attempted to adjust his art to the demands of his era. For instance, Arrowsmith has noted that in the Hellenic world, the destructive pressure of war breaks apart tradition and nature, appearance and reality, and the Euripidean drama is an attempt to view and analyze reality in relation to the new conception of human nature which was revealed by the crisis of war. (Strong, 1975, p. 169)

Strong (1975) holds the view that in Eurpides, the driving force is not a person or hero after the manner of Prometheus Bound. "Rather, one sees the working out of impersonal forces, to which the characters really have a peripheral relationship." He believes that Euripides concerns himself with "redemption from the blind order of universe." He is "a Schopenhauer of intellect. Virtue lies in resigned acceptance, in the pessimism of weakness." He presents the problem of "incommensurability of human desires" and sees its root in "a lack of prudence and definition." (p. 169-172) 
For Nietzsche (1956), tragedy and rationalism were not compatible. Plato gave up his interest in becoming a tragedian under the influence of Socrates, because he regarded tragedy incompatible with truth. Nietzsche considers it as a story of loss due to the fact that, for him, tragic knowledge is deeper than logical knowledge. However, Reiss accepts the disjunction between tragedy and philosophy but he views them as having a dynamic relationship at the moment of change. (Collits, 2000, p. 6-7) As the matter of knowledge is concerned, Strong (1975) seems to agree with Nietzsche in that he believes if one tries to decide on the basis of "accurate knowledge of the prudential consequences of one's actions", as with Eurpides, then, tragic and heroics will be impossible. (p. 176)

Eurpides' Medea appears to resist being categorized as portraying either a Dionysiac or Apollonian spirit, as it is filled with dualities which fluctuate between rationality and insanity on the Dionysiac-Apollonian continuum offered by Nietzsche. Is the child-murdering mother of Euripides' play rational or insane?

\section{MEDEA, APOLlONIAN OR DiONySiAn?}

Whether or not the act of infanticide is a matter of insanity or rationality on the part of Medea has been a controversial issue. Some consider Medea as the denunciation of Nietzsche's claim that Eurpides is an adherent of Socrates' rationality. However, there are other ways of interpreting the play and Medea's character, which could give the reader the clue that in Medea's case, child-murder is committed by careful thought and is decided due to good sense.

To answer the question of whether or not Euripides was an "artisan of Socrates' aestheticism" as Nietzsche claimed, Wildberg (2009) examines the evidence in Euripides plays, specifically Medea. He mentions a passage in Medea that has attracted the attention of scholars since it opposes Socrates' thinking and releases Euripides from Nietzsche's accusations. This is where Euripides portrays Medea's inner conflict as to whether to escape or take revenge. When Medea, finally, decides to commit infanticide against her good sense, she ends her monologue with the much discussed verses, which ever since Bruno Shell, have been considered contrary to the Socratic position that "reason harbors the strongest practical impulse." (Wilderberg 27-28) The passage reads as follows: "At last I understand the awful deed I am to do; but passion, that cause of direst woes to mortal man, hath triumphed o'er my sober thoughts." (Eurpides 45)

Since Medea is not an insane woman, Wilderberg continues, these lines could refute Socrates' thesis that "no one acts against his or her better judgment." Medea is aware of the internal conflict and in the end, she admits that her passion wins the upper hand, making her a person who "makes a terrible choice in spite of herself", what Socrates thought impossible. (p. 28)

However, as the opposition of reason and emotion is concerned, there are two other considerations of Medea's decision which are both perfectly rational. "One is the consideration of what would be right in the larger scheme of divine justice, and here the verdict was, from the beginning of the play, 'maximum penalty for Jason'." The other consideration is that, since her children were involved in the bride's murder, they would not escape the Corinthians' vengeance, thus, by killing the children herself she deprives the Corinthians of the opportunity to take revenge on her. (Wilderberg 28)

After her encounter with King Aegeus, Medea first announces her plan to kill her own children, this is when the Corinthian women protest against this change in her plan, and also call into question her intention to escape to Athens, "the birth place of harmony, home to all virtues, and especially renowned for wisdom." (Tessitore, 1991, p. 591) Finally, she takes refuge in the city of Athens. As Athens symbolizes Apollonian traits, Medea's departure to Athens after she commits murder can be indicative of the fact that she had acted logically.

Nietzsche (1956) maintains that Euripides' characters are not universalized and inspired by the power of music. To the contrary, they illustrate single, individualized personality traits, which are liable for violent passions. Their suffering is personal and does not comply with the demands of Dionysian tragedy, in that it fails to "express the eternal dialectic of the universal forces of nature and its inexorable laws." What replaces tragic action and heroic suffering is pathos and lamentation. (Pfeffer, 1972, p. 55-56)

However, in a view contrary to what Nietzsche believes, Medea appears to be looked upon as a champion by Corinthian women. "She gives voice to the injustices suffered by all women." When she expresses her will to "requite" those injustices, her promise "is not presented as the excessive desire of a fierce barbarian, but is embraced by the Corinthian women as their own." (Tessitore, 1991, p. 590) Since Medea has been treated unjustly, it seems logical for her as an abused individual to exact justice. Here, Medea becomes the voice of all women who suffer from maltreatment, and devises a careful plan to demand her rights.

Medea understands that to exact justice and uproot the house of Jason, her own children must die, for this is her motto:

Let no one deem me a poor weak woman who sits with folded hands, but of another mould, dangerous to foes and well-disposed to friends; for they win the fairest fame who live then, life like me. (Eurpides 31)

As these lines suggest, she believes that she belongs to the line of heroes; therefore, she seeks a life of glory which is by no means compatible with dishonor. (Tessitore, 1991, p. 593)

Thence, Medea feels the urge to take the path towards heroism, though it might make necessary such horrid an act as child murder. The fact that she is absorbed by the thought that she has no other choice than committing infanticide is in line with Nietzsche's assertion that Eurpides adds naturalistic effects to his treatment of the familiar myth. Besides, in other versions of Medea's myth, she does not kill her own children. 
Regarding this relationship between Socratism and naturalism, Nietzsche (1956) believes that Eurpides' intention was to evade the primordial and pervasive Dionysian element and rebuild tragedy based on a non-Dionysiac art and world-view. He pushed Dionysus out of stage and himself became a mask through which neither Apollo nor Dionysus could speak. It was Socrates, a new-born daemon, who spoke through him. He fought against Aeschylean tragedy with his Socratic tendency and conquered it. However he failed in building tragedy upon Apollonian elements and as a result he was led towards an inartistic naturalism. (p. 76-79)

It can be argued that if Medea's having no other choice than committing infanticide is naturalistic, then she has been acting upon the demands of nature, since reason and Socratic rationalism play no role in what is the inevitable outcome of natural circumstances. The question is that what is realistic is necessarily rationalistic and a product of reason? Here, Nietzsche's assertion that Eurpides adds naturalistic elements to his works is true; but, it could be put under question whether these naturalistic effects appear as the dramatist attempts to build his art upon Apollonian elements, or they come to the surface as a result of his tendency for a lifelike factual representation. The latter not only is not in opposition with the Dionysiac spirit of art as it keeps its connection with nature and reality, but also leads to a balance between nature and human's way of regarding it by basing the character's decision upon her understanding of natural forces and coordinating it with her senses.

However, Medea's motto--not allowing anyone to regard her as a weak woman-- in addition to citing the need for heroism discussed earlier, is suggestive of an issue with which Socrates was also concerned. Medea, as Tessitore (1991) declares, focuses on a single individual, in whom Euripides tries to display the problem of spiritedness. (p. 595) Spiritedness is a necessary quality for Medea. As Tessitore (1991) mentions, the issue of spiritedness is of importance to Socrates, where the Platonic Socrates "makes explicit the problematic character of spiritedness" in the discussion of warrior virtue, and talks about the fact that to construct a just city, the guardians must be gentle towards friends, and fierce towards enemies. (p. 595)

Medea can be seen as a character exhibiting rationality in that whatever she does is thought of and planned. She has a purpose in mind and does nothing out of blind passion. She has an aim--justice and heroism. To make her plans come true, she even does not allow maternal emotions to grasp her and give her cold feet. She believes it as her right to protest against injustice and exact her position and punish the wrong doer. These are the character traits that can put Medea in line with Apollonian, thus with reason and rationalism.

Besides, Nietzsche maintains that the supreme law of Euripides' esthetic Socratism is that "whatever is to be beautiful must also be sensible", the canon that shaped Euripides' diction, language, structure and choral music. As Nietzsche (p. 1956) suggests, the Euripidean prologue manifests this rationalistic method, as it starts with a character appearing right at the beginning of the play, talking about whom he is, what has happened and what the audience must expect. (p. 79) His esthetic principle is "whatever is to be beautiful must be conscious" which is parallel to the Socratic "whatever is to be good must be conscious." Therefore, he is "the poet of esthetic Socratism."(Nietzsche, 1956, p. 81)

Moreover, it must be noted that there exists no love and passion above maternal love, but Medea breaks the bonds of maternal affection for the sake of bringing about justice to her life. It is to say that Medea is not a character who yields to emotions, and even to love for her own children, and it places her a long distance away from the Dionysian. She does not attend to her nature as a mother, does not refer to her primordial emotions, and cuts of the bond of motherhood. She does not live for love or happiness; neither does she believe in unconditional love. She is harsh. Since she thinks they have done something wrong to her, she cuts them off and takes her life under her control.

In addition, the fact that Medea makes herself a unique mother by committing infanticide is in line with Apollonian notion of individuation, of separating one's self from the mass, and focusing on self-identity instead of creating a group identity with which the audience can identify themselves, a character trait that by no means comply with the Dionysiac.

At the beginning of the play, Medea's nurse complains that the poets' hymns completely lack wisdom and that they do not understand the pains and difficulties of life; rather, they try to accompany celebrations and music where they are least needed. Holding such a view, Euripides tries to expose the terrible misfortunes of life rather than pleasing his audience. (Tessitore, 1991, p. 601) The lines uttered by the nurse correspond to Nietzsche's assertion that Eurpides has broken away from the Dionysian spirit of tragedy, rendering unintelligible the musical origins of drama.

Jason's character bears almost the same conflicting interpretations. On the one hand, he seems to hold a logical view of his intention to marry the princess. He explains to Medea that he wants to get married for the well-being of his family and to give his sons the opportunity to have royal siblings and so getting them connected to the royal blood. On the other hand, his decisions are conceived to be irrational, not thought of, and due to passion when Medea's side is taken into account. His mistake is scolded by the chorus where they sing: "When in excess and past all limits Love doth come, he brings not glory or repute to man." (p. 24) This perception of love could be taken as exhibitive of Euripides's unDionysiac tendency towards the notion of love.

Jason's being blinded by passion and his ignorance is more clearly revealed when he yields to Creon's order that his sons be banished from Corinth, showing that he does not actually care for his family anymore; rather, he is absorbed in his passions. As Eurpides puts in the mouth of the character of the nurse: "What! will Jason brook such treatment of his sons, even though he be at variance with their mother?" (Eurpides 7)And later again the nurse laments: "O children, do ye hear how your father feels towards you? Perdition catch him, but no he is my master still; yet is he proved a very traitor to his nearest and dearest."(p. 8) And the attendant replies: 
And who 'mongst men is not? Art learning only now, that every single man cares for himself more than for his neighbor, some from honest motives, others for mere gain's sake? Seeing that to indulge his passion their father has ceased to love these children. (p. 8)

Thus, from the bystanders' point of view, Jason is seen as one who has succumbed to his passions, and it could give his betrayed wife, Medea, adequate reasons to take revenge and demand justice. Burian (1997) explains that the first and most obvious characteristic of conflict in tragedy is its extremity, meaning that "it does not ordinarily admit of compromise or mediation." Reconciliation of enemies generally occurs where there is "direct divine intervention." For Medea, accepting Jason's marriage is to deny her very nature. (p. 181)

\section{CONCLUSION}

As Nietzsche introduces the Dionysian as the origin of tragedy, and pronounces its death at the hands of Eurpides by his attempts to dissolve the roots and tilt the scale in favor of the Apollonian, the question of whether or not Medea, the child-murdering mother, complies with the tenets of Socratism and rational thinking comes to the surface. At first glance, we would hardly doubt that a mother who murders her children is blinded by passion or insanity, and we would take Medea as the embodiment of Dionysiac spirit in Euripides's tragedy, serving as a release from Nietzsche's accusations. Infanticide is naturally a shocking act of insanity and extremity, but when placed in the context of the play, it could be viewed from a different angle, justifying the deed as one of careful observance and devotion to logic and law. As a woman who has been treated unjustly, a victim who feels the vitality of exacting justice, and a champion who feels the urge to behave heroically, Medea dismisses maternal love, emotions and prosperity, and by murdering the children of her own, tries to punish the wrong doers. She is at the possession of immense ends, hers is an end put high above love and motherhood, by devotion to rationality.

\section{REFERENCES}

[1] Burian, P. (1997). Myth into Muthos: the Shaping of Tragic Plot. In P. E. Esterling (Ed.), The Cambridge Companion to Greek Tragedy. Cambridge Collections Online: Cambridge University Press.

[2] Collits, T. (2000). Intimations of Feminism in Ancient Athens: Euripides' Medea. Sydney Studies in English, 26 , p. 3-24.

[3] Cowan, R. B. (2007). Nietzsche's Attempted Escape from Schopenhauer's South Asian Sources in 'The Birth of Tragedy'. German Studies Review. 30 (3), 537-556.

[4] Euripides. Medea. (2007). [S.I]: Filiquarian Publishing.

[5] Kaufmann, W. A. (1968). Tragedy and Philosophy. Princeton: Princeton University Press.

[6] Mitchell-Boyask, R. (2008). Introduction. In Euripides, Medea (pp. vii-xii). Indianapolis: Hackett

[7] Nietzsche, F. (1956). The Birth of Tragedy and The Genealogy of Morals. Trans. Francis Golffing. Doubleday \& Company: New York.

[8] Nussbaum, M. C. (1988). The Transfigurations of intoxitation: Nietzsche, Schopenhauer and Dionysus. In S. Kemal, I. Gaskell, D. W. Convey (Eds.), Nietzsche, Philosophy and the Arts (36-69). Cambridge: Press Syndicate of Cambridge University.

[9] Pfeffer, R. (1972). Nietzsche: Disciple of Dionysus. Cranbury: Associated University Press.

[10] Silk, M. S, and Stern, J. P. (1981). Nietzsche on Tragedy. Cambridge: Press Syndicate of the University of Cambridge.

[11] Smith, P. C. (1998). The Hermeneutics of Original Argument: Demonstration, Dialectic, Rhetoric. Evanston: Northwestern University Press.

[12] Strong, T. B. (1975). Friedrich Nietzsche and the Politics of Transfiguration. Berkeley: University of California Press.

[13] Tessitore, A. (1991). Euripides's "Medea" and the Problem of Spiritedness. The Review of Politics, 53 (4), 587-601.

[14] Wildberg, C. (2009). Socrates and Euripides. In S. Ahbel-Rappe, R. Kamtekar, (Eds.), A Companion to Socrates (21-35). Chichester: Blackwell.

Bahee Hadaegh, born in Shiraz/ Iran, 08.01.1974. Ph.D. English literature, drama (NSW, Australia, Wollongong University, 2009). M.A. English literature (Shiraz, Iran, Shiraz State University, 2000). B.A. English literature (Kerman, Iran, Kerman State University, 1998).

She is presently working as Assistant Professor at department of English Literature, Shiraz State University, Shiraz, Iran. She is a full-time faculty member teaching Literature courses to M.A. and B.A. students. She is also thesis examiner of Ph.D. candidates. She has 9 years of teaching experience at different universities in addition to part-time jobs at IELTS centre at Wollongong University, NSW, Australia. More than four years of constant cooperation with Translation offices, translating literary, philosophical, technical, and medical texts.

Dr. Hadaegh's recently published book (Towards Ennobling Absence), Gemany, Lambert Publication, August 2012 is an inclusive study of the development of Western Tragedy which shows the influence of Persian Mysticism on Absurd plays. She has also published papers with TPLS, Kata, Epiphany, and Comparative Literature. Her specialty is Drama, Operas, and Comparative Studies focusing on Eastern Mysticism and Western Literature. Her idea about the effective applicability of literature in moral enhancement of societies is what supports the majority of her researches.

Parisa Shams, born in Shiraz/ Iran, 21.03.1988. M.A. English literature (Shiraz University, 2013). BA. English literature (Shiraz University, 2010). 
She has recently defended her M.A. thesis focusing on investigating the work of Edward Albee drawing upon gender theories of Judith Butler. She has also conducted research in other areas such as Jungian psychoanalysis, her most recent article being published in Jung Journal: Culture and Psyche 7.3 (May 2013). She is especially interested in drama and comparative study of philosophy and literature. 